\title{
JIMMBA
}

Jurnal Ilmiah Mahasiswa Manajemen, Bisnis dan Akuntansi

Homepage: http://journal.stieputrabangsa.ac.id/index.php/jimmba/index

\section{Analisis Kinerja Anggaran Berkonsep Value for Money}

\author{
M. Iqbal Ashari', M. Elfan Kaukab ${ }^{2}$ \\ 1 Universitas Sains Al-Qur'an \\ 2Universitas Muhammadiyah Yogyakarta \\ Email: asharr21@gmail.com¹, elvankaukab82@gmail.com²
}

\section{ARTICLE INFO}

Article History:

Received: October $2^{\text {nd }} 2020$

Accepted: October $16^{\text {st }} 2020$

Published: October 21st 2020

Keywords: Akuntabilitas,

Transparansi,

Pengawasan, Pemahaman

SAP, Kinerja Anggaran,

Value for money.

\begin{abstract}
Penelitian ini bertujuan untuk membuktikan pengaruh akuntabilitas, transparansi, pengawasan dan pemahaman standar akuntansi pemerintah terhadap kinerja anggaran berkonsep value for money di SKPD Kabupaten Banjarnegara. Pengambilan sampel dilakukan dengan slovin yang berjumlah 125 responden. Data yang diperoleh dianalisis dengan analisis regresi linier berganda dengan tingkat signifikan 5\%. Hasil perhitungan dengan pengujian parsial (uji t) dimana variabel akuntabilitas tingkat signifikansinya sebesar 0.050, variabel transparansi tingkat signifikansinya sebesar 0.026 , variabel pengawasan tingkat signifikansinya sebesar 0.010 , variabel pemahaman standar akuntansi pemerintah tingkat signifikansinya sebesar 0.293. Berdasarkan perhitungan tersebut diatas dapat disimpulkan bahwa variabel transparansi dan pengawasan mempunyai pengaruh terhadap kinerja anggaran berkonsep value for money sedangkan variabel Akuntabilitas dan Pemahaman Standar Akuntansi Pemerintah tidak mempunyai pengaruh terhadap kinerja anggaran berkonsep value for money. Keterbatasan dalam penelitian ini adalah sampel yang digunakan dalam penelitian ini hanya terbatas pada ASN bagian Bagian/Subbagian Perencanaan dan Keuangan, Bendahara SKPD dan Operator Simda di Kabupaten Banjarnegara. Presentase pengaruh akuntabilitas, transparansi, pengawasan, pemahaman SAP, dan kinerja anggaran berkonsep VFM pada ASN Bagian/Subbagian Perencanaan dan Keuangan, Bendahara SKPD dan Operator Simda di Kabupaten Banjarnegara sebesar $13,5 \%$. Sedangkan sisanya sebesar $86,5 \%$ dipengaruhi oleh variabel lain diluar dari penelitian ini. Agenda penelitian mendatang yaitu menambahkan masyarakat sebagai sampel dan menambah variabel-variabel lain yang berhubungan dengan kinerja anggaran berkonsep value for money agar hasil yang diperoleh semakin baik.
\end{abstract}

\section{Pendahuluan}

Nawa Cita adalah sembilan prioritas pembangunan lima tahun dari tahun 2014 sampai dengan tahun 2019. Demi terwujudnya nawa cita, pada poin agenda nawacita ketiga menjelaskan "Membangun Indonesia dari Pinggiran dengan Memperkuat Daerah-daerah dan 
Desa dalam Kerangka Negara Kesatuan" (Nasional Kompas, 2014) . Di masa pemerintahan Joko Widodo seluruh wilayah Indonesia memusatkan APBN dalam bidang pembangunan infrastruktur, dampak bagi daerah di tuntut untuk meningkatkan pengawasan serta mempertanggungjawabkan alokasi dana yang sudah di anggarkan secara akuntabel dan terbuka (Kaukab, 2020). Pada hakekatnya, pembangunan daerah merupakan kewenangan dari pemerintah daerah, baik Provinsi maupun Kabupaten atau Kota, dengan dukungan dan kerja keras para stakeholders (pemangku kepentingan) (Sekertariat Kabinet, 2020). Ketimpangan pemerataan perekonomian terjadi di Provinsi Jawa Tengah antara daerah di tengah, selatan dan utara. Wilayah selatan dianggap lebih maju dan mapan secara ekonomi. Faktor demografi turut berpengaruh dalam peningkatan kesejahteraan masyarakat, selain itu masalah banjir dan jalan yang rusak turut menjadi persoalan utama karena menghambat kemudahan akses bagi keberlangsungan kegiatan perekonomian, khususnya dalam pendistribusian barang akan menjadi terlambat dari waktu yang ditentukan (Suara Merdeka, 2018). Sebanyak 25 persen atau seperempat ruas jalan yang tanggung jawab pemeliharaannya berada di Pemkab Banjarnegara, mengalami kerusakan ringan hingga berat. Kepala Dinas Pekerjaan Umum dan Penataan Ruang Pemkab Banjarnegara, Tatag Rochyadi menyebutkan panjang jalan Kabupaten Banjarnegara yang menjadi wewenangnya dalam hal pemeliharaan mencapai sekitar $947 \mathrm{~km}$. Dengan keterbatasan keuangan APBD, dia menyebutkan tidak bisa seluruh ruas jalan yang rusak diperbaiki dengan melakukan peningkatan kualitas jalan (Nasional Republik, 2018). Bupati Banjarnegara Budi Sarwono terus berupaya mendorong pertumbuhan ekonomi di wilayah setempat melalui pembangunan infrastruktur jalan, dengan adanya akses jalan maka lebih mudah untuk mengangkut hasil perkebunan dan pertanian. Selain itu masyarakat bisa memanfaatkan jalan-jalan tersebut untuk berbagai aktifitas ekonomi lainnya (Jateng antara News, 2018). Tahun 2019 mendatang, Pemerintah Kabupaten Banjarnegara mempersiapkan anggaran sebesar Rp 400 miliar untuk perbaikan jalan (Satelitepos, 2018).

Dengan adanya kebutuhuan belanja pembangunan infrastruktur yang besar mengharuskan pemerintah menyusun secara matang dan memprioritaskan kegiatan dan alokasi anggaran yang ekonomis, efektif dan efisien (Ngakil dan Kaukab, 2020). Oleh karena itu saat berjalannya tahun anggaran berkaitan dan jika proses penyerapan anggaran gagal memenuhi target maka akan hilang manfaat belanja yang sudah di rencanakan. Menurut Peraturan Pemerintah Republik Indonesia Nomor. 71 tahun 2010 tentang Sistem Akuntansi Pemerintah (SAP) pada lampiran I.02, Sisa Lebih/Kurang Pembiayaan Anggaran (SILPA) adalah selisih lebih/kurang antara realisasi pendapatan Laporan Realisai Anggaran (LRA) dan belanja, serta penerimaan dan pengeluaran pembiayaan dalam APBD selama satu periode pelaporan Menurut Kementerian Keuangan Direktorat Jenderal Perimbangan Keuangan (2018) dalam penyusunan APBD angka SILPA ini seharusnya sama dengan nol artinya bahwa penerimaan pembiayaan harus dapat menutup defisit anggaran yang terjadi. Misalnya dalam APBD terdapat defisit anggaran sebesar Rp 100 Miliar, ditutup dengan penerimaan pembiayaan (pembiayaan netto) sebesar Rp 100 Miliar, maka SILPA-nya adalah Rp0, namun jika terdapat defisit anggaran sebesar Rp 100 Miliar dan ditutup dengan penerimaan pembiayaan (pembiayaan netto) sebesar Rp 120 Miliar (SILPA Positif), yang berarti bahwa secara anggaran masih terdapat dana dari penerimaan pembiayaan atau pembiayaan netto Rp 20 Miliar yang belum dimanfaatkan untuk membiayan Belanja Daerah dan/atau Pengeluaran Pembiayaan Daerah. SILPA Positif ini perlu dialokasikan untuk menunjang program-program pembangunan di daerah. Sisa anggaran pada akhir tahun anggaran yang disebut SILPA akan 
menjadi penerimaan pada awal tahun berikutnya merupakan indikator dalam menilai kualitas penganggaran pada pemerintah daerah (Abdullah, 2013).

Tabel 1. SILPA Kab. Banjarnegara

\begin{tabular}{lllr}
\hline \multicolumn{1}{c}{ Tahun Anggaran } & \multicolumn{1}{c}{ Keterangan } & \multicolumn{2}{c}{ Nominal } \\
\hline \multirow{2}{*}{2015} & (A) Surplus & $\mathrm{Rp}$ & 81.284 .274 .564 \\
& (B) Pembiayaan Netto & $\mathrm{Rp}$ & 313.040 .075 .054 \\
& (A+B = C) SILPA & $\mathrm{Rp}$ & 394.324 .349 .618 \\
2016 & (A) Defisit & $(\mathrm{Rp}$ & $181,367,885,015)$ \\
& (B) Pembiayaan Netto & $\mathrm{Rp}$ & 376.859 .089 .332 \\
2017 & (A+B = C) SILPA & $\mathrm{Rp}$ & 195.491 .204 .317 \\
& (A) Defisit & $(\mathrm{Rp}$ & $11,022,181,415)$ \\
& (B) Pembiayaan Netto & $\mathrm{Rp}$ & 183.271 .957 .898 \\
2018 & (A+B = C) SILPA & $\mathrm{Rp}$ & 172.249 .776 .483 \\
& (A) Defisit & $(\mathrm{Rp}$ & $44,443,521,507)$ \\
& (B) Pembiayaan Netto & $\mathrm{Rp}$ & 161.350 .044 .038 \\
& (A+B = C) SILPA & $\mathrm{Rp}$ & 116.906 .522 .531 \\
& (A) Defisit & $(\mathrm{RP}$ & $17,043,525,094)$ \\
& (B) Pembiayaan Netto & $\mathrm{Rp}$ & 105.201 .143 .340 \\
& (A+B = C) SILPA & $\mathrm{Rp}$ & 88.157 .618 .246 \\
\hline
\end{tabular}

Sumber: Data SIMDA Kab. Banjarnegara yang diolah, Tahun 2020.

Pada Tahun anggaran 2015 sampai dengan 2019 SILPA Kabupaten Banjarnegara mengalami penurunan akan tetapi sisa pembiayaan netto yang ada perlu di manfaatkan untuk mencapai tujuan dan program Bupati Banjarnegara dalam menyelesaikan masalah jalan Kabupaten Banjarnegara. Sisa anggaran mencerminkan kemampuan Pemerintah daerah dalam merealisasikan anggarannya serta keakurasian estimasi pendapatan, belanja dan pembiayaan yang ditetapkan sebelum pelaksanaan anggaran (Abdullah, et al.2015).

Anggaran merupakan suatu rencana keuangan yang meliputi pendapatan dan pengeluaran yang digunakan untuk mengestimasi kinerja di masa yang akan datang selama satu tahun. Kinerja adalah suatu kegiatan yang bertujuan untuk mencapai hasil yang diharapkan.Sistem penganggaran tersebut menggunakan pendekatan value for money (VFM) merupakan konsep pengelolaan organisasi sektor publik yang mendasarkan pada tiga elemen utama, yaitu ekonomi, efisiensi, dan efektivitas (Mardiasmo, 2002).Demi terwujudnya efisiensi dan efektivitas dalam pengelolaan keuangan perlu adanya akuntabilitas. Akuntabilitas sendiri dapat menjamin efisiensi dan efektivitas dalam pengelolaan anggarannya karena dari hasil pertanggungjawaban merupakan pemberian informasi dan pengungkapan atas aktivitas dan kinerja keuangan pemerintah kepada pihak-pihak yang berkepentingan. Pertanggungjawaban pelaporan secara terbuka dan jelas mengenai tujuan dapat menghindari anggapan masyarakat tentang penyalahgunaan anggaran yang dilakukan Satuan Kerja 
Perangkat Daerah (SKPD) yang bertindak sebagai agent (pengelola pemerintahan) (Masruhin dan Kaukab, 2019).

Suatu pemerintahan harus terbuka atau transparan untuk menyelenggarakan suatu sistem kebebasan aliran informasi dalam berbagai proses kelembagaan, sehingga mudah diakses oleh mereka yang membutuhkan (Haryanti dan Kaukab, 2019). Budi S Purnomo (2018) mengatakan transparansi juga berperan sebagai alat pengendalian atas kinerja yang dilakukan pemerintah. Pengawasan menurut Sarwoto (1968) dalam penlitian Shinta (2000) adalah kegiatan manajer yang mengusahakan agar pekerjaan terlaksana sesuai dengan rencana yang telah ditetapkan dan hasil yang dikehendaki. Di sisi lain, pengawasan ini juga dimaksudkan untuk menilai apakah setiap unit-unit telah melaksanakan kebijakan dan prosedur yang telah ditetapkan.

Menurut Peraturan Pemerintah Nomor 71 Tahun 2010 (2010) Standar Akuntansi Pemerintah (SAP) adalah rangkaian sistematik dari prosedur, penyelenggara, peralatan, dan elemen lain untuk mewujudkan fungsi akuntansi sejak analisis transaksi belanja sampai dengan pelaporan keuangan di lingkungan organisasi pemerintah. Hal ini berarti bahwa prosedur dalam analisis transaksi belanja dan menyusun laporan keuangan disusun berdasarkan pemahaman atas SAP yang rendah dapat mempengaruhi tercapainya kinerja Anggaran berkonsep value for moneyyang baik.

\section{Kajian Teori dan Telaah Literatur}

\section{Akuntabilitas}

Mardiasmo (2009) menyebutkan akuntabilitas dipahami sebagai kewajiban pihak pemegang amanah (agent) untuk memberikan pertanggungjawaban, menyajikan, melaporkan dan mengungkapkan segala aktivitas dan kegiatan yang menjadi tanggung jawabnya kepada pihak pemberi amanah (principal) yang memiliki hak dan kewenangan untuk meminta pertanggungjawaban tersebut. Ketika instansi pemerintah dapat mempertanggungjawaban penganggaran yang telah diberikan oleh masyarakat (horizontal) dan otoritas yang lebih tinggi (vertikal) dapat memberikan peningkatan kinerja anggaran berkonsep value for money pada instansi pemerintah.

$\mathbf{H}_{1}$ : Akuntabilitas berpengaruh positif terhadap kinerja anggaran berkonsep value for money

\section{Transparansi}

Menurut (Mardiasmo, 2006) definisi transparansi berarti keterbukaan (opennesess) pemerintah dalam memberikan informasi yang terkait dengan aktivitas pengelolaan sumber daya publik kepada pihak-pihak yang membutuhkan informasi. Ketika instansi pemerintah dapat menjamin akses atau kebebasan untuk memperoleh informasi bagi masyarakat dapat memberikan peningkatan pada kinerja anggaran berkonsep value for money pada instansi pemerintah.

$\mathbf{H}_{\mathbf{2}}$ : Transparansi berpengaruh positif terhadap kinerja anggaran berkonsep value for money

Pengawasan 
Pengertian pengawasan menurut Sarwoto (1968) adalah kegiatan manajer yang mengusahakan agar pekerjaan terlaksana sesuai dengan rencana yang telah ditetapkan dan hasil yang dikehendaki.Menurut Keputusan Menteri Keuangan No. 152 tahun 2011 (2011) menjelaskan bahwa pengawasan menurut sifatnya dapat dikelompokkan menjadi dua pengawasan preventif dan detektif.Widjaja (2002) mengatakan pengawasan preventif pada umumnya tidak dilakukan oleh unit-unit pengawasan yang telah ditetapkan. Pengawasan preventif ini biasanya berbentuk prosedur-prosedur yang harus di tempuh dalam melaksanakan kegiatan. Pengawasan preventif meliputi standar, desain formulir, formulirformulir yang dinomori (dinomori terlebih dahulu secara tercetak), dokumentasi, kata-kata sandi, konsistensi operasi. Pengawasan dilakukan oleh instansi pemerintah secara terusmenerus dapat memberikan efektivitas pengendalian anggaran dan memberikan peningkatan kinerja anggaran berkonsep value for money pada instansi pemerintah.

$\mathbf{H}_{3}$ : Pengawasan berpengaruh positif terhadap kinerja anggaran berkonsep value for money

\section{Pemahaman Standar Akuntansi Pemerintah}

Menurut Peraturan Pemerintah Nomor 71 Tahun 2010 (2010) Standar Akuntansi Pemerintah (SAP) adalah rangkaian sistematik dari prosedur, penyelenggara, peralatan, dan elemen lain untuk mewujudkan fungsi akuntansi sejak analisis transaksi sampai dengan pelaporan keuangan di lingkungan organisasi pemerintah. Pemahaman SAP adalah upaya untuk menafsirkan makna yang tertuang pada PP No.71 Tahun 2010 tentang SAP yang akan digunakan untuk menghasilkan suatu laporan keuangan yang andal dan dapat dijadikan pijakan dalam pengambilan keputusan dan yang di harapkan dapat menjadi acuan, patokan serta standar untuk diterapkan dalam lingkup pemerintahan, yaitu pemerintah pusat, pemerintah daerah dan satuan organisasi dilingkungan pemerintah pusat/daerah yang wajib untuk menyajikan laporan keuangan agar lebih terciptanya akuntabilitas dan transparansi dari pengelolaan keuangan daerah tersebut (Langelo, 2015). Kualitas laporan realisasi anggaran yang baik dapat tercapai jika Aparatur Sipil Negara (ASN) memiliki pemahaman Standar Akuntansi Pemerintah (SAP). Laporan realisasi anggaran yang baik yaitu demi terwujudnya misi tujuan instansi pemerintah dalam rangka untuk memberikan pelayanan terbaik bagi masyarakat selaku pihak principal dan akan berdampak pada peningkatan kinerja anggaran berkonsep value for money pada instansi pemerintah.

$\mathbf{H}_{4}$ : Pemahaman Standar Akuntansi Pemerintah berpengaruh positif terhadap kinerja anggaran berkonsep 


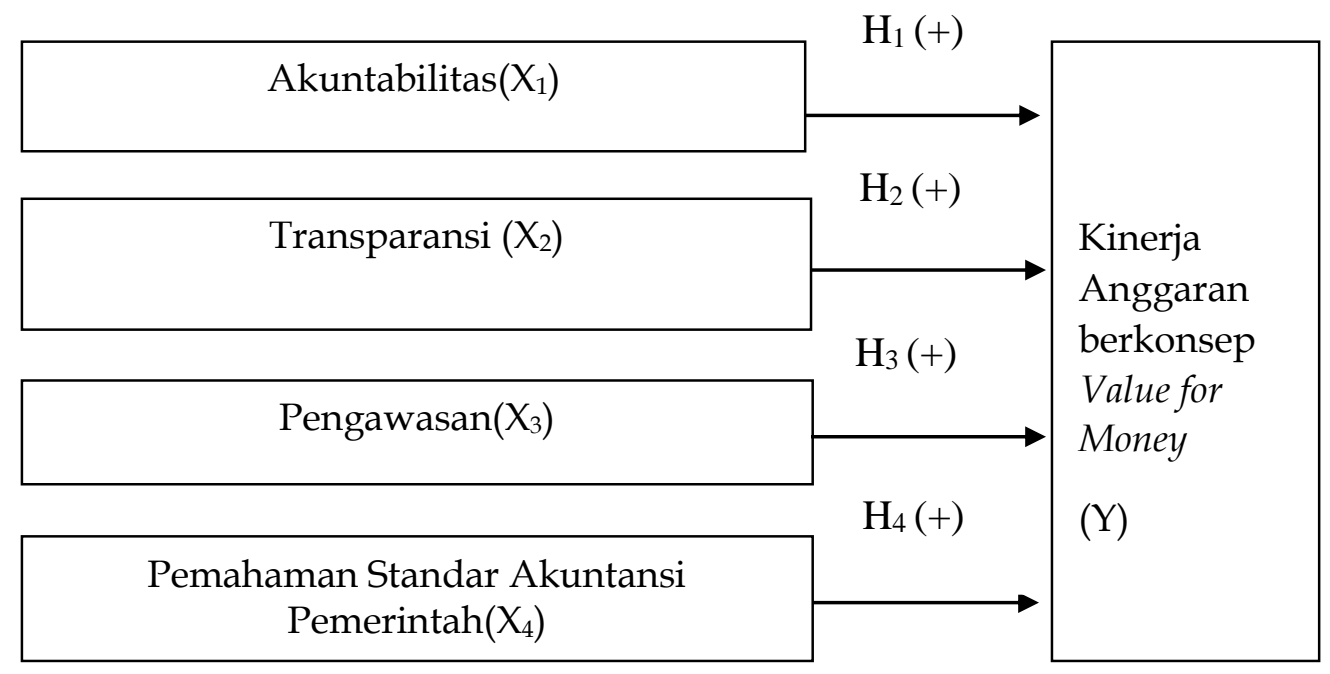

\section{Gambar 1. Model Penelitian}

\section{Metode Penelitian}

Jenis penelitian yang dilakukan dalam penelitian ini adalah penelitian kuantitatif dan sumber data yang digunakan dalam penelitian ni yaitu data primer serta skunder. Populasi dalam penelitian ini adalah ASN (Aparatur Sipil Negara) sebagai Bagian/Subbagian Perencanaan dan Keuangan, Bendahara SKPD, dan Operator Simda di satuan kerja perangkat daerah (SKPD) Kabupaten Banjarnegara periode tahun 2020 yang berjumlah 43 SKPD. Dengan asumsi ASN yang berkerja di setiap SKPD mempunyai 4 orang ASN yang memenuhi kriteria masa kerja lebih dari atau sama dengan 1 Tahun Anggaran, jadi jumlah seluruh sampel 172 orang. Pengumpulan data dalam penelitian ini dilakukan dengan cara membagikan kuesioner secara langsung dan google form adapun batas waktu penyebaran kuesioner adalah dua minggu dan kuesioner yang dibagikan berjumlah 172 butir kuesioner. Data diolah menggunakan analisis regresi berganda dengan bantuan SPSS.

\section{Hasil dan Pembahasan}

Pengumpulan data dalam penelitian ini dilakukan dengan cara membagikan kuisioner secara langsung dan google form kepada Kepala Bagian/Subbagian Perencanaan dan Keuangan, Bendahara SKPD dan Operator Simda di Kabupaten Banjarnegara. Adapun batas waktu penyebaran kuesioner adalah dua minggu dan kuesioner yang dibagikan berjumlah 172 butir kuesioner. Untuk memberikan gambaran mengenai variabel-variabel penelitian yaitu akuntabilitas, transparansi, pengwasan, dan pemahaman SAP, kinerja anggaran berkonsep VFM digunakan tabel statistik deskriptif mengenai variabel-variabel yang digunakan dalam penelitian yang diuraikan dalam dalam $\mathrm{N}$ (jumlah responden), range correlations, minimum, maximum, mean, dan standard deviation yang dapat dilihat dalam tabel berikut: 
Tabel 2. Statistik Deskriptif Variabel

\begin{tabular}{lrrrrr}
\hline \multicolumn{1}{c}{ Valid } & \multicolumn{1}{c}{$\begin{array}{c}\text { Std. } \\
\text { Deviation }\end{array}$} & $\begin{array}{c}\text { Kisaran } \\
\text { Aktual }\end{array}$ & $\begin{array}{c}\text { Rata-Rata } \\
\text { Aktual }\end{array}$ & $\begin{array}{c}\text { Kisaran } \\
\text { Teoritis }\end{array}$ & $\begin{array}{c}\text { Rata-Rata } \\
\text { Teoritis }\end{array}$ \\
\hline Akuntabilitas & 3.907 & $8-24$ & 16.88 & $5-24$ & 14.5 \\
Transparansi & 3.746 & $8-24$ & 18.03 & $5-24$ & 14.5 \\
Pengawasan & 3.863 & $8-25$ & 18.31 & $5-25$ & 15 \\
Standar Akuntansi & 5.234 & $8-25$ & 15.17 & $5-25$ & 15 \\
$\begin{array}{l}\text { Pemerintah } \\
\text { Kinerja Anggaran }\end{array}$ & 3.878 & $8-24$ & 18.12 & $5-24$ & 14.5 \\
VFM & & & & & \\
\hline
\end{tabular}

Sumber: Data Primer diolah (2020)

Dari Tabel 2 dapat diketahui distribusi kisaran teoritis, kisaran aktual, rata-rata dan standar deviasi. Karena semua nilai rata-rata aktual lebih tinggi dari pada rata-rata teoritis, sehingga dapat dijelaskan bahwa responden dalam penelitian ini berpendapat penerapam akuntabilitas, transparansi, pengwasan di SKPD sudah baik, pemahaman SAP yang dimiliki ASN SKPD sudah baik, dan kinerja anggaran berkonep VFM yang dimilki SKPD Kab. Banjarnegara sudah maksimal.

Tabel 3. Pengujian Good Offit (Uji F)

\begin{tabular}{|c|c|c|c|c|c|c|}
\hline \multicolumn{2}{|c|}{ Model } & $\begin{array}{l}\text { Sum of } \\
\text { Squares }\end{array}$ & df & Mean & $\mathrm{F}$ & Sig. \\
\hline & Regression & 251.186 & 4 & 62.797 & 4.669 & $.002^{\mathrm{b}}$ \\
\hline \multirow[t]{2}{*}{1} & Residual & 1614.014 & 120 & 13.450 & & \\
\hline & Total & 1865.200 & 124 & & & \\
\hline
\end{tabular}

Berdasarkan Tabel 3 diperoleh hasil uji $\mathrm{F}$ (Goodness of Fit) dengan tingkat signifikan 0,002 yang berarti lebih kecil dari 0,05. Sehingga dapat disimpulkan bahwa variabel akuntabilitas, transparansi, pengwasan, pemahaman SAP, dan kinerja anggaran berkonsep VFM sudah sesuai atau Fit sehingga secara bersama-sama dapat mempengaruhi kinerja anggaran berkonsep value for money. Dalam pengujian kualitas pada uji validitas dinyatakan valid dimana taraf signifikansi pada tingkat 0.000 . Kemudian secara keseluruhan uji reliabilitas yang dilakukan dalam penelitian ini telah menunjukkan hasil dengan nilai cronbrach alpha yang lebih besar dari 0,6. Sehingga seluruh pertanyaan yang berkaitan dengan varibaelvariabel penelitian yaitu akuntabilitas, transparansi, pengawasan, pemahaman SAP, dan kinerja anggaran berkonsep VFM adalah reliabel.

Uji asumsi klasik dihasilkan perhitungan normalitas dengan menggunakan uji One-Sample Kolmogorof-Smirnof Test memiliki probabilitas tingkat signifikan diatas tingkat $\alpha=0,05$ yaitu 0,200 . Hal ini berarti dalam model regresi regresi terdapat variabel residual yang terdistribusi secara normal. Pada uji multikolonieritas menunjukkan bahwa semua variabel independen memiliki nilai Tolerance kurang dari 0,1. Selanjutnya hasil perhitungan VIF juga menunjukkan hasil yang sama yaitu semua varibael independen memiliki nilai VIF lebih dari 10. Sehingga dapat disimpulkan bahwa tidak terjadi multikolonieritas antara variabel independen dalam model regresi. Hasil uji heterokedastisitas yang diuji dengan 
menggunakan uji glejser menunjukkan bahwa semua variabel bebas (independent) memiliki nilai signifikansi diatas 0,05 . Sehingga dapat disimpulkan bahwa model regresi tidak ada heterokedastisitas.

Pengujian hipotesis dilakukan dengan menggunakan regresi linier berganda dengan hasil sebagai berikut:

Tabel 4. Hasil Uji Hipotesis

\begin{tabular}{|c|c|c|c|c|c|c|}
\hline & \multirow[t]{2}{*}{ Model } & \multicolumn{2}{|c|}{$\begin{array}{l}\text { Unstandar } \\
\text { dized Coeffi } \\
\text { cients }\end{array}$} & \multirow{2}{*}{$\begin{array}{c}\begin{array}{c}\text { Standar } \\
\text { dized Coeffi } \\
\text { cients }\end{array} \\
\text { Beta }\end{array}$} & \multirow[t]{2}{*}{$t$} & \multirow[t]{2}{*}{ Sig } \\
\hline & & B & $\begin{array}{l}\text { Std. } \\
\text { Error }\end{array}$ & & & \\
\hline \multirow{5}{*}{1} & (Constant) & 8.548 & 2.841 & & 3.009 & .003 \\
\hline & Akuntabilitas & .167 & .085 & .169 & 1.977 & .050 \\
\hline & Transparansi & .200 & .089 & 193 & 2.252 & .026 \\
\hline & Pengawasan & .227 & .086 & .226 & 2.632 & .010 \\
\hline & $\begin{array}{l}\text { Standar } \\
\text { Akuntansi } \\
\text { Pemerintah }\end{array}$ & -.067 & .063 & -.090 & 1.055 & .293 \\
\hline
\end{tabular}

Berdasarkan Tabel 4 di atas dapat diperoleh persamaan regresi sebagai berikut: $Y=8,548+0,167 X 1+0,200 X 2+0,227$ X3 - 0,067 X4 + 3,667

Persamaan regresi di atas memiliki makna:

1. Nilai konstanta (a) sebesar 8,548 (positif), menunjukkan bahwa ketika variabel independen (akuntabilitas, transparansi, pengawasan, pemahaman SAP) dalam keadaan konstans $(\mathrm{x}=$ $0)$, maka SKPD yang menjadi sampel dalam penelitian ini cenderung memiliki kinerja anggaran berkonsep value for money yang baik.

2. Hasil pengujian regresi linier berganda menunjukkan bahwa variabel akuntabilitas memiliki koefisien regresi sebesar 0,167 dengan nilai signifikansi 0,050. Nilai ini sama dengan nilai signifikansi 5\% (0,05). Dengan demikian, maka hipotesis pertama yang menyatakan bahwa akuntabilitas berpengaruh positif terhadap kinerja anggaran berkonsep value for money di tolak.

3. Hasil pengujian regresi linier berganda menunjukkan bahwa variabel transparansi memiliki koefisien regresi sebesar 0,200 dengan nilai signifikansi 0,026. Nilai ini lebih kecil dari nilai signifikansi 5\% $(0,05)$. Dengan demikian, maka hipotesis kedua yang menyatakan bahwa transparansi berpengaruh postif terhadap kinerja anggaran berkonsep value for money di terima artinya semakin baik keterbukaan informasi pemerintah daerah maka semakin baik kinerja anggaran berkonsep value for money yang dihasilkan, dengan asumsi variabel lainnya dianggap konstan.

4. Hasil pengujian regresi linier berganda menunjukkan bahwa variabel pengawasan memiliki koefisien regresi sebesar 0,227 dengan nilai signifikansi 0,010. Nilai ini lebih kecil dari nilai signifikansi 5\% (0,05). Dengan demikian, maka hipotesis ketiga yang menyatakan bahwa pengawasan berpengaruh positif terhadap kinerja anggaran berkonsep value for 
money di terima artinya semakin baik pengawasan yang di terapkan pemerintah daerah, maka semakin baik kinerja anggaran berkonsep value for money yang dihasilkan, dengan asumsi variabel lainnya dianggap konstan.

5. Nilai koefisien regresi dari variabel pemahaman standar akuntansi pemerintah sebesar 0,067 dengan nilai signifikan sebesar 0,293. Nilai ini lebih besar dari nilai signifikansi 5\% $(0,05)$. Dengan demikian, maka hipotesis keempat yang menyatakan bahwa pemahaman standar akuntansi pemerintah berpengaruh positif terhadap kinerja anggaran berkonsep value for money di tolak.

Hasil pengujian hipotesis pertama (H1) menunjukkan bahwa akuntabilitas berpengaruh terhadap kinerja angagran berkonsep value for money. Hal ini tidak sesuai dengan hipotesis awal yang menyatakan bahwa akuntabilitas berpengaruh positif terhadap kinerja anggaran berkonsep value for money. Hasil penelitian ini berbeda dengan hasil penelitian A.A Sagung Ary Nur Arista dan I Wayan Suartana (2016) membuktikan bahwa semakin kuat dan tinggi akuntabilitas yang dimiliki oleh suatu instansi pemerintahan maka akan semakin berpengaruh baik pada hasil akhir dari kinerja anggaran instansi pemerintahan tersebut. Namun Hasil penelitian Cindy Arfiyani (2018) membuktikan akuntabilitas tidak berpengaruh terhadap kinerja anggaran berbasis value for money. Penelitian ini membuktikan akuntabilitas tidak berpengaruh terhadap kinerja anggaran berkonsep value for money. Artinya pelaksanaan pertanggungjawaban yang dilakukan SKPD di Kabupaten Banjarnegara dalam dalam menyajikan informasi mengenai keputusan atau program yang telah di rencanakan tidak mempengaruhi kinerja anggaran berkonsep value for money. Hal tersebut terlihat hasil evaluasi SAKIP (Sistem Akuntabilitas Kinerja Instansi Pemerintahan) Tahun 2017 sampai sekarang ada beberapa SKPD masih mendapatkan nilai $C$ yang menandakan ada sebagian SKPD tidak melaksanakan pertanggungjawaban dengan baik. Namun Hasil evaluasi SAKIP Tahun 2019 Kabupaten Banjarnegara mendapat predikat B, Sekda Indarto meminta kepada seluruh pimpinan Perangkat Daerah untuk mengawal implementasi SAKIP di Perangkat Daerah mulai dari renstra, RKT, renja, cascading, pengukuran kinerja hingga pelaporan kinerja. Menurut Kepala Bagian Organisasi sampai saat ini harus diakui bahwa implementasi SAKIP Kabupaten Banjarnegara masih perlu ditingkatkan.

Hasil pengujian hipotesis kedua (H2) menunjukkan bahwa transparansi berpengaruh terhadap kinerja angagran berkonsep value for money. Hal ini sesuai dengan hipotesis awal yang menyatakan bahwa transparansi berpengaruh positif terhadap kinerja anggaran berkonsep value for money (H2 diterima). Hasil penelitian Cindy Arifani (2018) transparansi berpengaruh terhadap kinerja anggaran berbasis value for money dimana anggaran harus disajikan secara terbuka dan jelas mengenai tujuan, sasaran, hasil, dan manfaat yang diperoleh masyarakat dari suatu kegiatan atau proyek yang dianggarkan oleh pemerintah. Keterbukaan pemerintah dalam penyempaian informasi kepada masyarakat dan pihak-pihak membutuhkan, dalam pengelolaan anggaran yang berorientasi ekonomi, efisien dan efektivitas dapat meningkatkan capaian suatu kegiatan, program, dan kebijakan dalam mewujudkan tujuan pemerintah. Dapat dilihat dari jawaban 125 responden, sebagian besar responden menjawab setuju, yang artinya bahwa responden dalam penelitian ini sudah memahami pentingnya kebebasan aliran informasi kepada masyarakat berdasarkan 
pertimbangan masyarakat memiliki hak untuk mengetahui pengelolaan anggaran yang dipercayakan pemerintah daerah. Hal tersebut dapat di lihat usaha Pemerintah Kabupaten Banjarnegara melalui website DINKOMINFO (Dinas Komunikasi dan Informasi) yang memuat berbagai informasi terbaru tentang kegiatan pemerintah daerah.

Hasil pengujian hipotesis ketiga (H3) menunjukkan bahwa pengawasan berpengaruh terhadap kinerja angagran berkonsep value for money. Hasil pengujian hipotesis menunjukkan bahwa pengawasan berpengaruh positif terhadap kinerja anggaran berkonsep value for money. Hal ini sesuai dengan hipotesis awal yang menyatakan bahwa pengawasan berpengaruh positif terhadap kinerja anggaran berkonsep value for money (H3 diterima). Hasil penelitian Arif Fajri (2018) mengatakan pengawasan preventif berpengaruh terhadap efektivitas pengendalian anggaran. Pelaksanaan pengawasan oleh pemerintah daerah sebelum program atau kegiatan dilaksanakan, dalam pengelolaan anggaran yang berorientasi ekonomi, efisien dan efektivitas dapat meningkatkan capaian suatu kegiatan, program, dan kebijakan dalam mewujudkan tujuan pemerintah. Dapat dilihat dari jawaban 125 responden, sebagian besar responden menjawab setuju, yang artinya bahwa responden dalam penelitian ini sudah memahami pentingnya pengawasan preventif dalam kegiatan penyusunan anggaran karena pengawasan preventif dapat mencegah permasalahan yang akan timbul. Berdasarkan wawancara dengan kasie anggaran di BPPKAD Kab. Banjarnegara, dalam proses penyusunan RKA yang diawasi bidang anggaran masih terdapat kesalahan penomeran, dan nama rekening hal tersebut menunjukkan pentingnya pengawasan preventif dalam penyusunan anggaran agar pelaksanaan realisasi anggaran berjalan optimal.

Hasil pengujian hipotesis keempat (H4) menunjukkan bahwa pemahaman standar akuntansi pemerintah berpengaruh terhadap kinerja angagran berkonsep value for money. Hasil pengujian hipotesis menunjukkan bahwa pengawasan berpengaruh positif terhadap kinerja anggaran berkonsep value for money. Hal ini tidak sesuai dengan hipotesis awal yang menyatakan bahwa pemahaman standar akuntansi pemerintah berpengaruh positif terhadap kinerja anggaran berkonsep value for money (H4 ditolak). Hasil penelitian ini tidak sesuai dengan hasil penelitian Nurul Hutami Ningsih (2017) mengatakan Standar Akuntansi Pemerintah (SAP) berpengaruh signifikan terhadap pelaksanaan dan penatausahaan APBD berkonsep value for money sehingga perlu diterapkan dalam praktik di lapangan. Namun hasil penelitian Nurul Hutami Ningsih (2017) mengatakan secara parsial bahwa SAP tidak signifikan memoderasi hubungan antara pengetahuan akuntabilitas, pengetahuan transparansi dan pengetahuan pengawasan terhadap penatausahaan APBD berkonsep VFM. Penelitian ini menunjukkan bahwa pemahaman standar akuntansi pemerintah tidak berpengaruh terhadap kinerja anggaran berkonsep value for money. Artinya, sebagian besar ASN di Kabupaten Banjarnegara belum memiliki pemahaman tentang standar akuntansi pemerintah sebagai dasar menyusun laporan keuangan yang andal dan dapat jadikan pijakan pengambilan keputusan tidak mempengaruhi kinerja anggaran berkonsep value for money. Berdasarkan wawancara dengan kasie akuntansi di BPPKAD Kab. Banjarnegara, pada saat pemeriksaan BPK Laporan Keuangan berdasarkan SAP di susun bidang akuntansi dengan aplikasi SIMDA oleh karena itu banyak responden belum memiliki pemahaman SAP dengan baik. Namun Hasil evaluasi SAKIP Tahun 2019 Kabupaten Banjarnegara mendapat predikat 
B, Sekda Indarto meminta kepada seluruh pimpinan Perangkat Daerah untuk mengawal implementasi SAKIP di Perangkat Daerah mulai dari renstra, RKT, renja, cascading, pengukuran kinerja hingga pelaporan kinerja. Menurut Kepala Bagian Organisasi sampai saat ini harus diakui bahwa implementasi SAKIP Kabupaten Banjarnegara masih perlu ditingkatkan (RRI, 2019).

Tabel 5. Uji Determinasi

\begin{tabular}{crrrrr}
\hline Model & R & R Square & $\begin{array}{c}\text { Adjusted R } \\
\text { Square }\end{array}$ & $\begin{array}{l}\text { Std. Error of } \\
\text { the Estimate }\end{array}$ & $\begin{array}{r}\text { Durbin- } \\
\text { Watson }\end{array}$ \\
\hline 1 & $.367^{a}$ & .135 & .106 & 3.667 & 2.258 \\
\hline
\end{tabular}

Tabel 5 menunjukkan nilai adjusted $\mathrm{R}$ square sebesar 0,106 atau 10,6\%, hal ini menunjukkan bahwa variabel minat investasi saham dapat dijelaskan oleh variabel akuntabilitas, transparansi, pengwasan, pemahaman SAP sebesar 13,5\%, sedangkan sisanya sebesar $86,5 \%$ disebabkan oleh faktor-faktor lain yang tidak dijelaskan dalam penelitian ini.

\section{Penutup dan Saran}

Berdasarkan hasil penelitian ini maka dapat disimpulkan bahwa ada atau tidak adanya pelaksanaan pertanggungjawaban yang dilakukan SKPD di Kabupaten Banjarnegara dalam dalam menyajikan informasi secara berkala mengenai keputusan atau program yang telah di rencanakan tidak mempengaruhi kinerja anggaran berkonsep value for money. Pertanggungjawaban dalam pengelolaan anggaran harus dilaksanakan SKPD Kabuapten Banjarnegara untuk menjaga amanat masyarkat serta mencapai visi dan misi pemerintah dalam rangka perwujudan good governance. Yang kedua website DINKOMINFO sebagai tempat informasi terbaru tentang kegiatan pemerintah daerah adalah salah satu bentuk transparansi pemerintah daerah kepada masyarakat. Hal tersebut meningkatkan kinerja anggaran berkonsep value for money pada pemerintah Kabupaten Banjarnegara. Ketiga, pengawasan yang dilakukan bidang anggaran saat penyusunan RKA sebagai salah satu bentuk pengawasan dalam pengelolaan anggaran, Hal tersebut meningkatkan kinerja anggaran berkonsep value for money pada pemerintah Kabupaten Banjarnegara. Dan keempat disimpulkan bahwa ASN memahami atau tidak memahami standar akuntansi pemerintah sebagai dasar dalam menyusun laporan realisasi anggaran, tidak mempengaruhi kinerja anggaran berkonsep value for money di SKPD Kabupaten Banjarnegara.Pemahaman SAP merupakan modal yang harus dimiliki ASN untuk menyusun laporan keuangan yang andal, relavan dan sebagai pijakan untuk pengambilan kebijakan SKPD Kabupaten Banjarnegara.

Berdasarkan hasil penelitian ini diharapkan dapat memberikan manfaat bagi pemerintah Kabupaten Banjarnegara dalam mencapai visi dan misi Pemerintah Daerah bersama masyrakat. Untuk tercapainya visi dan misi dapat dilakukan dengan cara meningkatkan kinerja anggaran yang berorientasi ekonomi, efisiensi dan efektivitas yang melalui pertanggungjawaban pemerintah daerah atas aktivitas atau kegiatan yang dijalankan, melalui keterbukaan penyampaian, kebijkan, peraturan, aktivitas dan informasi pemerintah daerah kepada masyarkat, melalui pengawasan yang dilakukan pemerintah daerah unutuk 
tercapainya visi misi, melalui PP No. 71 Th 2010 tentang SAP yang digunkanan sebagai dasar untuk menghasilkan laporan keuangan yang andal dan dapat dijadikan pijakan dalam mengambil keputusan.

\section{Referensi}

Ardita, E. (2017). Pengaruh Transparansi, Akuntabilitas, Dan Pengawasan Terhadap Kinerja Anggaran Berkonsep Value for Money Pada Instansi Pemerintah Di Kabupaten Ogan Ilir. Doctoral Dissertation. Politeknik Negeri Sriwijaya.

Arifani, C., Salle, A., \& Rante, A. (2018). Pengaruh Akuntabilitas, Transparansi dan Pengawasan Terhadap Kinerja Anggaran Berbasis Value For Money. Jurnal Akuntansi Dan Keuangan Daerah, 13(1), 68-82.

Arista, A. S. A. N., \& Suartana, I. W. (2016). Pemahaman Atas SAP Sebagai Pemoderasi Pengaruh Akuntabilitas dan Transparansi pada Kinerja Anggaran SKPD Kota Denpasar. E-Jurnal Akuntansi, 17(2), 1667-1699.

Davis, J. H., Schoorman, F. D., \& Donaldson, L. (1997). Toward a stewardship theory of management. Academy of Management review, 22(1), 20-47.

Fajri, A. (2018). Pengaruh Pengawasan Preventif dan Pengawasan Detektif terhadap Efektifitas Pengendalian Anggaran. Menara Ilmu, 12(6), 1-9.

Haryanti, S., \& Kaukab, M. E. (2019). Analisis Transparansi Dan Akuntabilitas Laporan Keuangan Masjid Di Wonosobo (Sstudi Empiris Pasa Masjid Yang Terdaftar Di Kemenag Kabupaten Wonosobo Tahun 2019). Journal of Economic, Business and Engineering (JEBE), 1(1), 140-149.

Jateng Antar News. 2017. Https://Jateng.Antaranews.Com/Berita/177904/ Banjarnegara-Prioritaskan-Anggaran-Untuk-Pembangunan-Infrastruktur

Kaukab, M. E. (2020). Indonesian Economic Outlook 2020: Peluang Dari Keterbukaan. Jurnal Penelitian dan Pengabdian Kepada Masyarakat UNSIQ, 7(1), 38-47.

Langelo, F., Saerang, D. P. E., \& Alexander, S. W. (2015). Analisis penerapan standar akuntansi pemerintahan berbasis akrual dalam penyajian laporan keuangan pada pemerintah kota bitung. Jurnal EMBA: Jurnal Riset Ekonomi, Manajemen, Bisnis dan Akuntansi, 3(1), 2303-1174.

Mardiasmo. (2002). Otonomi Dan Manajemen Keuangan Daerah. Penerbit ANDI, Yogyakarta

Mardiasmo. (2006). Perpajakan, Edisi Revisi, Penerbit Andi, Yogyakarta.

Mardiasmo. (2009). Akuntansi Sektor Publik, Yogyakarta: ANDI.

Masruhin, A., \& Kaukab, M. E. (2019). Pengaruh kompetensi aparatur, komitmen organisasi, partisipasi masyarakat, dan kejelasan sasaran anggaran terhadap pengelolaan dana desa (studi empiris pada perangkat desa di kecamatan mojotengah Kabupaten Wonosobo). Journal of Economic, Business and Engineering (JEBE), 1(1), 118-130. 
Ngakil, I., \& Kaukab, M. E. (2020). Transparansi dan Akuntabilitas Pengelolaan Keuangan Desa di Kabupaten Wonosobo. Journal of Economic, Management, Accounting and Technology (JEMATech), 3(2), 92-107.

Ningsih, N. H. (2018). Pengaruh Pengetahuan Tentang Akuntabilitas, Transparansi Dan Pengawasan Terhadap Pelaksanaan Dan Penatausahaan Apbd Berkonsep Value for Money Dengan Standar Akuntansi Pemerintah (Sap) Di Skpd Kota Palembang. BALANCE: JURNAL AKUNTANSI DAN BISNIS, 2(1), 171-191.

Nugroho, L. S. (2016). Pengaruh Pengangaran Berbasis Kinerja, Pengawasan Preventif Dan Pengawasan Fungsional Terhadap Efektifitas Pengendalian Anggaran Keuangan Daerah (Studi Empiris Pada Satuan Kerja Perangkat Daerah Kabupaten Grobogan). Doctoral Dissertation. Universitas Muhammadiyah Surakarta.

PP No. 71 Tahun 2010. 2010. Tentang Standar Akuntansi Pemerintahan

Ruwaida, R., Darwanis, D., \& Abdullah, S. (2015). Faktor-faktor yang Mempengaruhi Realisasi Anggaran Belanja Pendidikan di Provinsi Aceh. Jurnal Administrasi Akuntansi: Program Pascasarjana Unsyiah, 4(4), 101-110.

SIMDA (Sistem Informasi Managemnt Daerah). 2020. LRA Tahun Anggaran 2015, 2016, 2017,2018 Kab. Banjarnegara, Bid. Anggaran By SIMDA, 2020

Sugiyono. (2012). Metode Penelitian Kuantitatif Dan Kualitatif Dan RED. Bandung: Alfabeta

Thomas, P. W., \& Williams, P. (2004). EDP Pengendalian dan Auditing. Erlangga, Edisi, Jakarta. 